\title{
Pénzügyi területen dolgozó értékesítők aspirációinak vizsgálata ${ }^{12}$
}

\author{
Juhász István \\ Eszterházy Károly Egyetem, Eger
}

\begin{abstract}
A KUTATÁS CÉLJA
A kutatás alapvető célja egy olyan üzletkötői személyiségprofil felállítása - az Aspirációs kérdőív segítségével - mely megkönnyíti az üzletkötői álláshirdetésekre jelentkezők kiválasztását - illetve felvételük esetén - későbbi motiválását, vezetését a pénzügyi, biztosítási tevékenység nemzetgazdasági ág területén.
\end{abstract}

\begin{abstract}
ALKALMAZOTT MÓDSZERTAN
A vizsgálat alanyai a jelenleg pénzügyi területen, azon belül is értékesítői munkakörben dolgozó munkavállalók. Elsősorban a bankokban, biztosítóknál, lakástakarékpénztárakban, pénzügyi tanácsadóknál, valamint faktorcégeknél, lízingcégeknél, takarékszövetkezeteknél és tőzsdei vállalatoknál tevékenykedő értékesítők személyisége került górcső alá. A vizsgálati alanyok online az internet segítségével töltötték ki a kérdőíveket. A mintavétel a nem véletlen mintavételi eljárások közül, a hólabda-mintavételi eljárás révén történt. A begyüjtött adatok elemzése és kiértékelése az Excel és az SPSS programok segítségével zajlott. Megállapításra került különböző szempontok alapján, hogy mekkora a minta átlaga, annak szórása, valamint gyakoriságokkal és megoszlási viszonyszámokkal is dolgoztam. A statisztikai próbák közül az egymintás t-próbát használtam.
\end{abstract}

\section{LEGFONTOSABB EREDMÉNYEK}

A vizsgált, pénzügyi területen dolgozó üzletkötők mintájában az Aspirációs-kérdőívben elért eredmények alapján statisztikailag igazolható mértékben a következő életcélok térnek el a standard értékektől: Gazdagság, Hírnév, Imázs, Növekedés, Kapcsolat és Egészség. Statisztikailag igazolható mértékben nem térnek el lényegesen az elvárt értéktől a minta Társadalom aspirációban adott értékei. A nők esetében szintén a Társadalom, míg a férfiak esetében a Kapcsolat és az Egészség életcélokban nem volt lényeges, statisztikailag igazolható eltérés a standard átlagértékek és a mintát alkotó nők és férfiak eredményei között, az összes többi életcél esetében van lényeges, statisztikailag igazolható eltérés.

\section{GYAKORLATI JAVASLATOK}

A pénzügyi területen tevékenykedő értékesítők kiválasztásában alkalmazandó Aspirációs-kérdőív eredményei alapján elsősorban az extrinzik aspirációkban (Gazdagság, Hírnév, Imázs) elért, átlagtól magasabb eredmények meglétét tekintsék pozitív - egyben szükséges, de nem elégséges - feltételnek a vállalatok döntéshozói! Továbbá az intrinzik aspirációk esetében a nőknél a Növekedés, Kapcsolat és Egészség, míg a férfiaknál a Növekedés és a Társadalom életcélok átlagtól való magasabb eltérését vegyék pozitívumnak!

Kulcsszavak: üzletkötők, pénzügy, biztosítás, aspirációs kérdőív

DOI: https://doi.org/10.15170/MM.2019.53.02.08

\footnotetext{
1 A tanulmány egy - várhatóan 2019-ben a Miskolci Egyetem Vállalkozáselmélet és Gyakorlat Doktori Iskolájában védésre kerülő - doktori értekezés részét képezi.

2 A tanulmány az EFOP 3.6.1-16-2016-00001 „Kutatási kapacitások és szolgáltatások komplex fejlesztése az Eszterházy Károly Egyetemen" projekt keretén belül - a doktori fokozatszerzés megindításának támogatására kiírt pályázat támogatásával készült el.
} 


\section{BEVEZETÉS}

Kiből lesz jó értékesítő? Egyáltalán ki számít jó értékesítőnek? Kinek a szemszögéből? Az ügyfelek, a vezetők, esetleg a kolléganők és kollégák véleményét kell figyelembe venni ezen kérdés megválaszolásánál? Többségünknek volt már tapasztalata a pénzügyi területen tevékenykedő értékesítővel. Legyen szó bankszámlanyitásról, hitelfelvételről, biztosítási ajánlat kéréséről, vagy akár pénzügyi tanácsadásról. Mennyire hasonlítottak egymásra ezek az értékesítők? Sokszor magunk is megdöbbenünk azon, hogy mennyire nem. Egyik közvetlenebb, a másik távolságtartóbb, az egyik lezserebb, a másik kimértebb. Többségük más-más cél- és eszközrendszerrel próbálja elérni nálunk a sikert, még akkor is, ha sokszor különféle képzések keretén belül törekednek a vállalatok „standardizálni” munkatársaik értékesítési törekvéseit. Legtöbbjük sikere személyiségükből fakad. Vajon ki alkalmas erre a sikerekkel és kudarcokkal kikövezett pályára? Létezik olyan egzakt módszer, amivel el lehet dönteni, hogy kiből lesz jó értékesítő a pénzügyek területén?

A jelen tanulmányban bemutatott kutatás alapvető célja egy olyan üzletkötői személyiségprofil felállítása - az aspirációs kérdőív segítségével -, mely megkönnyíti az üzletkötői álláshirdetésekre jelentkezők kiválasztását a pénzügyi, biztosítási tevékenység nemzetgazdasági ág területén. Az így kialakított profil segítségével megállapítható, hogy egy üzletkötői munkakörre jelentkező pályázó aspirációs jellemzői, életcéljai, motivációi alapján megfelel-e a szakma és a vállalatok általános elvárásainak vagy sem, illetve az is, hogy a későbbiekben mely eszközökkel lehet motiválni az adott értékesítőt. A profil felhasználható emellett az üzletkötők munkahelyi beillesztési programjának testre szabásához, munkahelyi szocializációjuk elősegítéséhez (Kozák 2015).

\section{A KUTATÁS MÓDSZERTANA: A VIZSGÁLAT ALANYAI, MÉRÉS, ADATGYÜJTÉS, ELEMZÉS}

\section{A vizsgálat alanyai}

A vizsgálat alanyai a jelenleg pénzügyi területen, azon belül is értékesítói munkakörben dolgozó munkavállalók. A bankoknál, a biztosító társaságoknál, a lakás-takarékpénztáraknál, a pénzügyi tanácsadóknál dolgozó foglalkoztatottak alapsokaságából az ügyfelekkel közvetlenül, személyes kontaktusba kerülő értékesítők kerültek a kutatás középpontjába. Elsősorban a bankokban, a biztosítóknál, a lakás-takarékpénztárakban, a pénzügyi tanácsadóknál, valamint a faktorcégeknél, a lízingcégeknél, a takarékszövetkezeteknél és a tözsdei vállalatoknál tevékenykedő értékesítők személyisége került górcső alá.

\section{Mérés, adatgyüjtés}

A mérés során az alábbiakban felsorolt - zárt és nyitott kérdésekre épülő - részekből álló online kérdőív került kitöltetésre a vizsgálati személyekkel:

1. Alapadatok,

2. Aspirációs kérdőív.

A vizsgálat során intim, személyes jellegü kérdések is felvételre kerültek, ezért az egyes kérdésekre adott konkrét válaszokat és azok eredményeit szigorúan a vizsgálati alanyok személyes adataiként, bizalmasan kezeltem. Amennyiben a válaszadók kérték, akkor személyre szabott kiértékelést kaphattak az egyéni vizsgálati eredményeikről. Az eredmények e-mailben, excel fájl formájában lettek elküldve, melyben az adatok táblázatok és diagramok formájában kerültek részletezésre. Kiküldésre került továbbá egy 18 oldalas Word dokumentum is, mely az eredmények részletes magyarázatát tartalmazta.

Az adatgyüjtés legfontosabb ismérvei:

- A kérdőív megszerkesztésére, kialakítására, tesztelésére, javítására és véglegesítésére 2016. november és december hónapjaiban került sor.

- A kérdőív online módon 2016. december 14. és 2017. július 20. között volt kitölthetö.

- A mintavétel a nem véletlen mintavételi eljárások közül, a hólabda-mintavételi eljárás révén történt. Megkeresésre kerültek továbbá olyan nagyobb, a pénzügyi, 
biztosítási tevékenység nemzetgazdasági ághoz kapcsolódó szervezetek és azok tagjai közvetlen vagy közvetett formában, mint a Magyar Bankszövetség, a Magyar Biztosítók Szövetsége, az Országos Takarékszövetkezeti Szövetség, a Pénzügyi Vállalkozások Országos Egyesülete, a Magyar Lízingszövetség, a Magyar Kereskedelmi és Iparkamara, a Magyar Közgazdasági Társaság.

- 1069 fö töltötte ki teljes egészében a kérdőívet.

- 1000 fö eredményei kerültek bele a véglegesített mintába, 69 fö eredményeit különböző okok (pl. nem releváns munkakör, nem releváns gazdasági ág stb.) miatt ki kellett szürni a mintából.
A minta legfontosabb demográfiai jellemzőit az alábbiakban részletezem. A válaszadók nemek szerinti megoszlásáról elmondható, hogy a nők jelentős „túlsúlyban” vannak $(62,2 \%)$ a férfiakhoz $(37,8 \%)$ képest. Ez az arány csaknem megegyezik a TEÁOR szám szerinti a Központi Statisztikai Hivatal által publikált a pénzügyi, biztosítási tevékenységet végző foglalkoztatottak 2016. évre vonatkozó arányaival (nők 61,98\%, férfiak 38,02\%), (KSH 2017a).

Születési idő szerint legtöbben az 1971 és 1980 közötti évtizedből képviseltették magukat, a minta 30,7\%-át adva (1. ábra). A legidősebb kitöltő egy 1933-as szegedi férfi, míg a legfiatalabb kitöltők 1998-as születési idejű nők voltak (egy budapesti és egy jászsági). Születési évszám szerint a legtöbben, összesen 45-en az 1970-ben születettek közül töltötték ki a kérdőívet.

\section{1. ábra: A válaszadók születési idő szerinti csoportosítása (fö)}

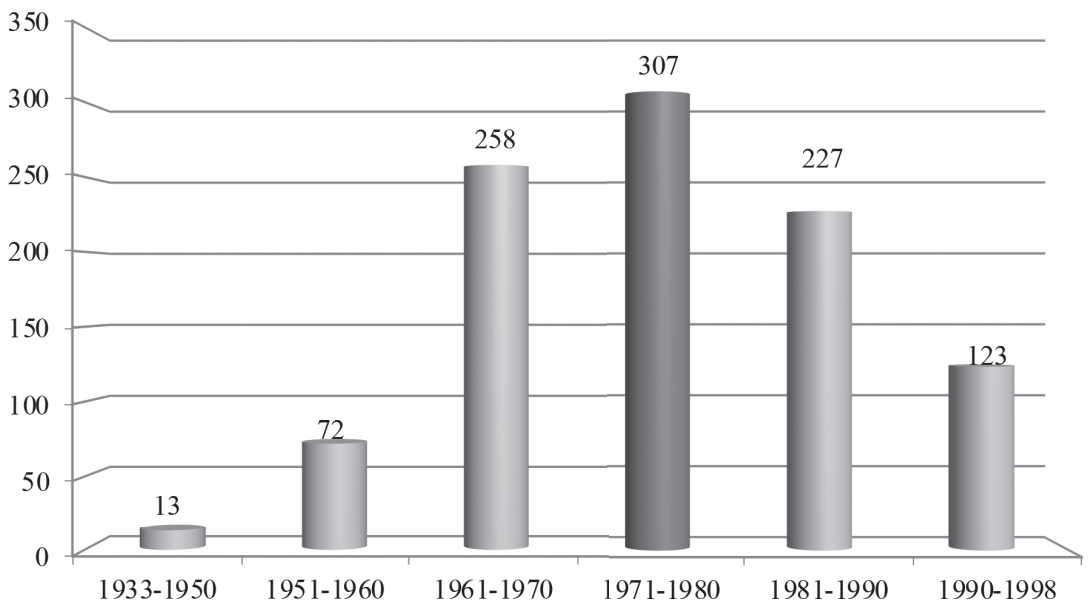

Forrás: saját szerkesztés

Lakóhelyük szerint a vizsgálatban résztvevőknek a megyeszékhelyen vagy megyei jogú városokban lakók adták a minta többségét, 32,8\%-át (2. ábra). A 2011. évi Népszámlálás adatai alapján a magyar népesség településtípusonkénti megoszlása némiképp eltér a minta adataitól (főváros: 17,4\%; megyeszékhely, megyei jogú város: 20,42\%; többi város: 31,65\%; községek, nagyközségek: 30,53\%; (KSH 2017b)). Így a minta nem mondható ebben az értelemben reprezentatívnak. 


\section{2. ábra: A válaszadók lakóhelyének településtípusa szerinti csoportosítása (fö)}

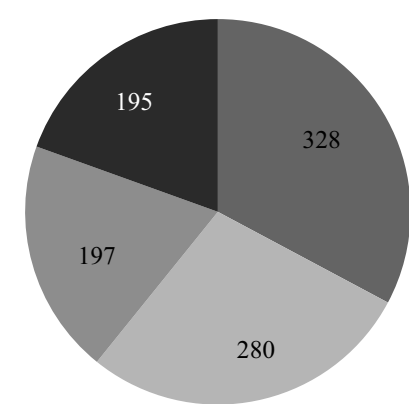

Forrás: saját szerkesztés

\section{Elemzés}

A begyüjtött adatok elemzése és kiértékelése az excel és az SPSS programok segítségével történt. Megállapításra került különböző szempontok alapján, hogy mekkora a minta átlaga, annak szórása, valamint gyakoriságokkal és megoszlási viszonyszámokkal is dolgoztam. A statisztikai próbák közül az egymintás t-próbát alkalmaztam.

Összevetésre kerültek a mintát alkotó vizsgálati személyek válaszai a magyar mintán standardizált eredményekkel. Összehasonlításra kerültek továbbá az egyes ágazatok (bank, biztosítás, pénzügyi tanácsadás, lakás-takarékpénztár) üzletkötőinek kérdőívben elért eredményei egymással is.

\section{AZ ASPIRÁCIÓS-KÉRDŐÍV BEMUTATÁSA}

Az Aspirációs Index hosszú távú célok és aspirációk feltárására szolgáló kérdőívet Kasser és Ryan (1996) szerzőpáros dolgozta ki, a Deci és Ryan (1985) által megalkotott úgynevezett ,öndeterminációs elmélet" folyományaként.

Az öndeterminációs elmélet egy pozitív szemléletü önszabályozási modell, amely tanuláselméleti és humanisztikus alapokra épült. Olyan társas környezetben lezajló személyiségfejlődésre és személyiségmüködésre vonatkozó, humán motivációs makroelmélet, melyben az ember egy aktív organizmus, akinek veleszületett célja, hogy uralja és kezelje a folyamatos változásokat és kihívásokat, valamint egy koherens én-érzésbe integrálja tapasztalatait, miközben pszichológiailag folyamatosan növekedik és fejlödik. Az elmélet kidolgozói az extrinzik és intrinzik motívumokat, úgynevezett aspirációk formájában fogalmazták meg. Véleményük szerint a legalapvetőbb motivációk (aspirációk,
- Megyeszékhely, megyei jogú város

— Többi város

- Főváros

- Község, nagyközség életcélok) kategóriái a következők: gazdagság, hírnév, imázs, növekedés, kapcsolat, társadalom és egészség. Az extrinzik aspirációk ezek alapján a gazdagságra és vagyonra, a hírnév elérésére és az imázsra irányuló életcélok, míg az intrinzik aspirációk a személyes növekedésre, a társas kapcsolatok kialakítására és fenntartására, valamint a közösségi és társadalmi célok, továbbá az egészség elérésére irányuló törekvések (V. Komlósi és tsai 2006, 238239).

A pszichológiailag egészséges személy alapszükségletei azok, amelyek az egyén autonómiáját, kompetens cselekvésre való képességét, pozitív kapcsolatok iránti vágyát elégítik ki. Ezekre a szükségletekre alapvetően belülről vezérelve - intrinzik módon - vagyunk motiváltak, míg a jutalmak és a külső elvárások keresésére - azaz az extrinzik motivációra - kívülről. Az extrinzik motiváció az intrinzik motivációval ellentétben alacsonyabb jóléttel és alacsonyabb szintủ személyiségmüködéssel jár, mivel a külső feltételekhez kötött jutalmak az igazi, belső szükségleteket nem elégítik ki. Tehát a megfelelő intrinzik életcélokra való törekvés elengedhetetlen annak érdekében, hogy pszichológiailag egészségesen működjünk és teljesebb életet éljünk (Martos 2010, 37-39).

Számos vizsgálat használta fel Deci és Ryan (1985) munkáját. Elméletük alapján Tremblay et al. (2009) egy új 18 itemből álló kérdéssort fejlesztettek ki a munkavállalók motivációjának vizsgálatára. A katonák (465 fö) és civilek (192 fö) körében felvett kérdőíves kutatásuk eredménye szerint az „öndeterminált" motiváció növekedésével nő a munka iránti elköteleződése a dolgozóknak, míg a kevésbé „öndetermináltan” motivált munkavállalók ritkábban segítenek kollégáiknak és hajlamosak a deviáns viselkedésre is. „Az Aspirációs Indexszel 
folytatott kiterjedt kutatások azt jelzik, hogy az extrinzik célok viszonylagos előnyben részesítése valóban negatívan kapcsolódik a mentális egészség számos indikátorához (pl. depresszió, szorongás), míg az intrinzik célok viszonylagos erőssége pozitívan korrelál a jóllét (boldogság, elégedettség) és a mentális egészség mértékével." (Martos és tsai 2006, 173).

Az identifikált szabályozás során a személy a viselkedését önmaga számára értelmesként és értékesként fogja fel, ez a szabályozás önmeghatározott, akárcsak az intrinzik motivációjú viselkedés esetében. Kutatások szerint a pénzügyi sikerek hajszolása rosszabb lelki egészséggel jár, míg a közösség iránti elköteleződés jobb lelki egészségi állapottal függ össze. Igaz azonban, hogy a pénzügyi sikerek előtérbe helyezése is lehet kedvező hatású, de ehhez az kell, hogy ez a vágy valójában önmeghatározott legyen, azaz magát a folyamatot találjuk élvezetesnek (Kasser 2002, Kasser \& Ryan 1993, Carver \& Scheier 2006). Kasser (2002) fiatal felnőttek körében végzett kutatása szerint, azoknak, akiknek életében a pénz és a hírnév meghatározó szerepet játszik, kevesebb vitalitásról és „öndetermináltságról” illetve magasabb depresszióról számoltak be, mint a pénzt és a hírnevet kevesebbre tartó vizsgálati személyek. A szerző több tanulmány összegzése alapján megállapítja, hogy az anyagias szemléletü emberek kevésbé elégedettek az életükkel, mint nem anyagias szemléletü társaik. Egyes kutatási eredmények arra engednek következtetni, hogy önmagában , csak” az amerikai álomra, azaz a pénzügyi sikerre történő törekvés szignifikáns elörejelzője (prediktora) lehet az alacsonyabb szintü önmegvalósításnak.

$\mathrm{Az}$ intrinzik típusú ember számára is fontos az elismerés vagy a pénz, mert ha nem érnek el ezek egy bizonyos alapszintet, akkor motivációja megrendül, függetlenül attól, hogy az intrinzik vagy az extrinzik típusba tartozik-e. Amennyiben azonban a jövedelem összege elér egy bizonyos szintet, akkor egészen más értékkel bír a pénz egy intrinzik és egy extrinzik típusú ember életében. Ekkor ugyanis az intrinzik típusú ember már magára a munkára tud koncentrálni, míg az extrinzik típusú ember számára továbbra is a pénz a kulcsfontosságú tényező. Tehát az intrinzik típusú embernek is fontos a munkájának elismerése, de önmagában nem az elismerés elérése a cél, szemben az extrinzik típussal (Pink 2010).

Az Aspirációs Index kérdőívet hazai mintán V. Komlósi és munkatársai vették fel. A standardizáltnak tekinthető vizsgálat eredményeit az alábbi táblázat tartalmazza (1. táblázat).

\section{1. táblázat: Az Aspirációs-kérdőív leíró statisztikái és a mérőeszköz skáláinak reliabilitása $(n=537)$}

\begin{tabular}{|c|c|c|c|c|c|c|c|c|}
\hline \multirow{2}{*}{ Változó } & \multicolumn{2}{|c|}{ Nők } & \multicolumn{2}{|c|}{ Férfiak } & \multirow{2}{*}{$\begin{array}{l}\text { t-próba } \\
\text { t (p) }\end{array}$} & \multicolumn{2}{|c|}{ Együtt } & \multirow{2}{*}{$\begin{array}{l}\text { Cronbach- } \\
\text { alfa }\end{array}$} \\
\hline & átlag & szórás & átlag & szórás & & átlag & szórás & \\
\hline Gazdagság & 4,36 & 1,22 & $4,66^{* *}$ & 1,15 & $2,71(0,00)$ & 4,46 & 1,20 & 0,81 \\
\hline Hírnév & 2,86 & 1,31 & 3,04 & 1,56 & $1,41(0,16)$ & 2,92 & 1,40 & 0,86 \\
\hline Imázs & $4,44 * *$ & 1,36 & 3,61 & 1,40 & $6,49(0,00)$ & 4,17 & 1,43 & 0,84 \\
\hline Növekedés & $6,33 * *$ & 0,75 & 6,11 & 0,82 & $2,95(0,00)$ & 6,26 & 0,78 & 0,72 \\
\hline Kapcsolat & $6,34 * *$ & 0,85 & 6,01 & 0,94 & $2,71(0,00)$ & 6,24 & 0,89 & 0,76 \\
\hline Társadalom & $5,36^{* *}$ & 1,19 & 4,79 & 1,42 & $4,87(0,00)$ & 5,18 & 1,29 & 0,89 \\
\hline Egészség & $6,50 * *$ & 0,72 & 6,20 & 0,87 & $4,21(0,00)$ & 6,41 & 0,78 & 0,82 \\
\hline Intrinzik* & $6,01 * *$ & 0,77 & 5,64 & 0,86 & $4,88(0,00)$ & 5,89 & 0,82 & 0,88 \\
\hline Extrinzik & 3,89 & 1,12 & 3,77 & 1,16 & $1,09(0,27)$ & 3,85 & 1,13 & 0,91 \\
\hline
\end{tabular}

Magyarázat: *Az Intrinzik aspiráció az Egészséget nem tartalmazza. ${ }^{*} p<0,01$

Forrás: V. Komlósi és tsai 2006, 242 
A kérdőív kitöltése során a vizsgálati személyeknek egy hét fokozatú skálán kellett eldönteniük, hogy az adott aspiráció mennyire fontos a számukra, ahol az egyes az egyáltalán nem fontos, a hetes a nagyon fontos értéket jelentette a skálán.

\section{PÉNZÜGYI TERÜLETEN DOLGOZÓ ÉRTÉKESÍTŐK SZEMÉLYISÉGPROFILJA AZ ASPIRÁCIÓS-KÉRDŐÍV ALAPJÁn}

A hivatkozott szakirodalmak áttekintése, valamint a vonatkozó kutatások eredményei alapján arra számítottam, hogy az Aspirációs kérdőív üzletkötők körében felvett eredményeit összevetve a magyar mintán standardizált értékekkel a Gazdagságra, a Növekedésre és a Kapcsolatokra irányuló életcélok esetében kapok a standard értékektől statisztikailag kimutatható, pozitív eltérést, így a következő hipotézist fogalmaztam meg:
H1: Az Aspirációs kérdöív üzletkötők körében felvett eredményeit összevetve a magyar mintán 2006-ban standardizált értékekkel a Gazdagságra, a Növekedésre, és a Kapcsolatokra irányuló életcélok esetében van a standard értékektől statisztikailag kimutatható, pozitív eltérés.

Az Aspirációs-kérdőív alapján a kutatásban részt vevő értékesítők az alábbiakban részletezett átlageredményeket érték el az egyes életcélok esetében (3. ábra). Az ábráról - meglepő módon - az olvasható le, hogy a lehetséges négy intrinzik aspiráció közül három - Egészség, Kapcsolat, Növekedés - szerepel a dobogón és a negyediket (Társadalom/Közösség) is csak „orrhosszal” ( 0,2 ponttal) előzte meg a Gazdagság életcél, holott ez utóbbi került volna a várakozások szerint az első helyre (különös tekintettel a minta pénzügyi jellegére vonatkozóan). Elsősorban tehát nem a gazdagság vagy a pénz motiválja/motiválhatja az üzletkötőket a pénzügyi, biztosítási tevékenység nemzetgazdasági ágban, hanem más „,belülről” fakadó értékek és célok.

\section{3. ábra: A válaszadók Aspirációs-kérdőív alapján elért átlageredményei (pont)}

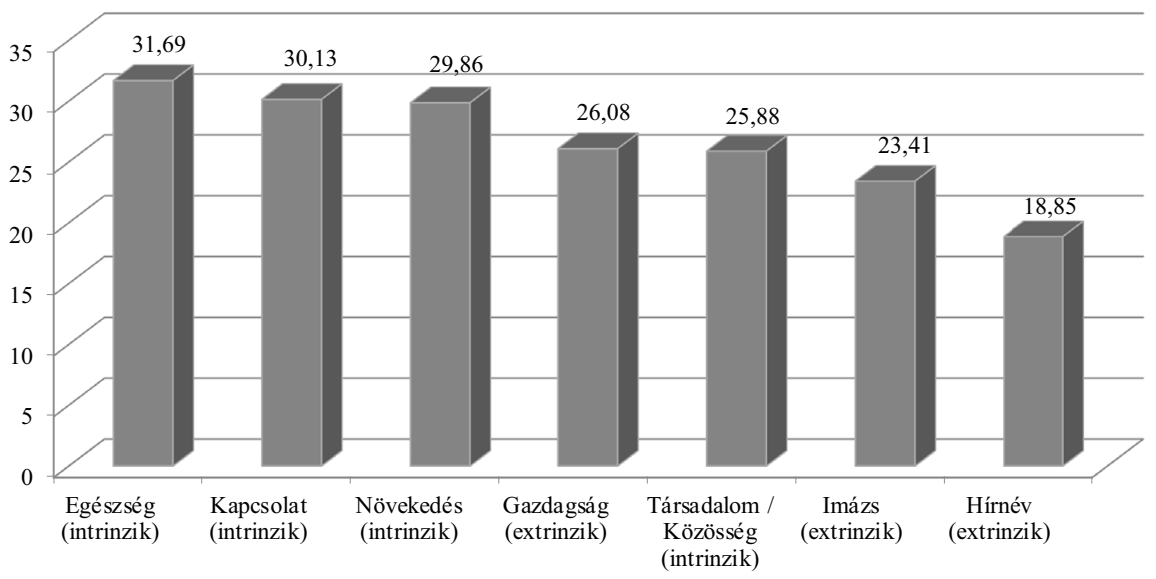

Forrás: saját szerkesztés 
A válaszadók egyes aspirációkra vonatkozó kérdésekre adott pontjainak átlageredményeit és azok eltérése a standard értékektől a 4. ábra mutatja be. Amennyiben összehasonlítjuk az egyes aspirációk nők és férfiak körében elért pontértékeit, meglepő eredményekre jutunk (5. ábra). A nök magasabb pontértékeket értek el a következő életcélok esetében: Egészség, Kapcsolat, Növekedés, Társadalom/ Közösség és Imázs. (A nők ezen aspirációkban elért pontos átlageredményei az ábrán piros alapon szerepelnek). Látható, hogy az összes intrinzik valamint egy extrinzik (az Imázs) aspiráció tekintetében is túlszárnyalták a férfiakat, akik - talán nem meglepő módon - két extrinzik életcél esetében bizonyultak „erősebbnek” (pontértékeik kék alapon láthatóak az ábrán). Egyike ezeknek a Gazdagság (családfenntartó mivoltukból adódóan ez az eredmény előrevetíthető volt), a másik pedig a Hírnév (a férfiakban erősebb a motiváció arra, hogy valami nagyszabású célt elérjenek, valami grandiózus dolgot megvalósítsanak, esetleg egy vállalat, intézmény hierarchiájának csúcsára kerüljenek). A két nem eredményei között a legnagyobb abszolút érték szerinti különbség az Imázs $(1,94)$, a Hírnév $(-1,56)$ és a Társadalom/Közösség $(1,47)$ aspirációk terén van. Ezek közül az első és a harmadik életcél tekintetében a nők, míg a második tekintetében a férfiak adtak magasabb pontszámokat a vonatkozó kérdésekre.

\section{4. ábra: A válaszadók egyes aspirációkra vonatkozó kérdésekre adott pontjainak átlageredményei és azok eltérése a standard értékektől (pont)}

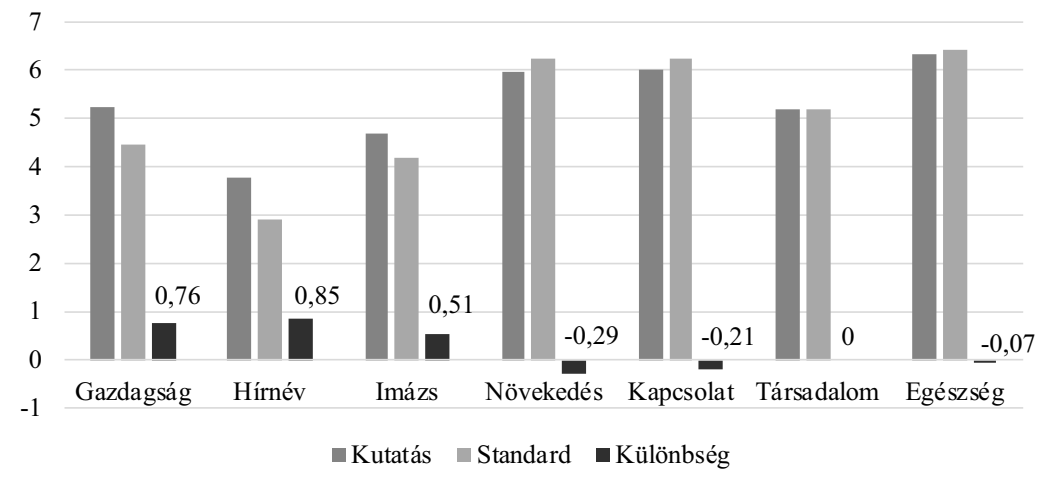

Forrás: saját szerkesztés

5. ábra: A válaszadók Aspirációs-kérdőív alapján elért, nemek szerinti átlageredményei és azok különbsége (pont)

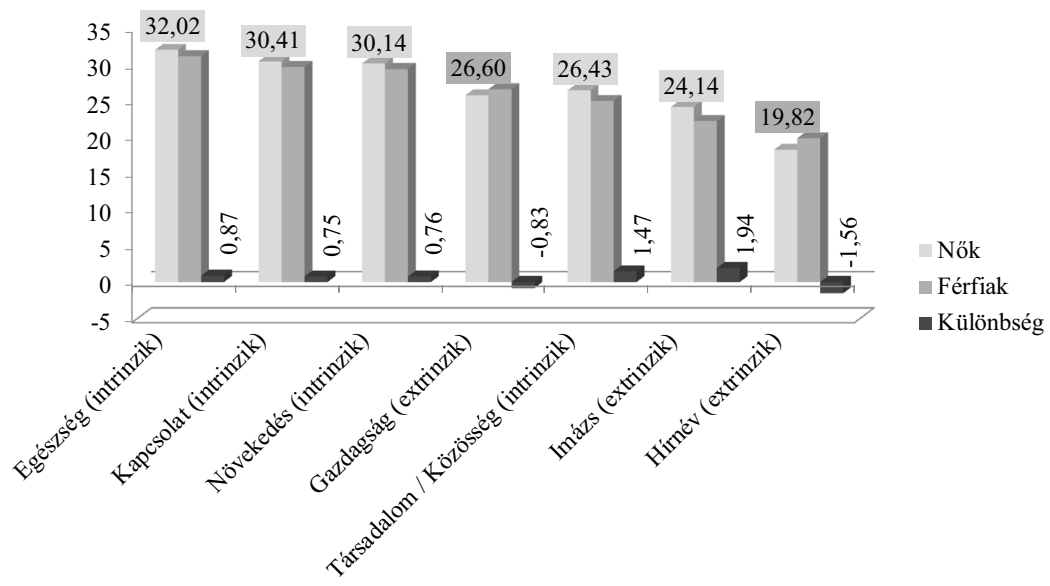

Forrás: saját szerkesztés 
2. táblázat: Az Aspirációs-kérdőív leíró statisztikái és t-próbái* aspirációnként, nemenként és együttesen a kutatásban résztvevők eredményei alapján $(n=1000)$

\begin{tabular}{|l|l|l|l|l|l|l|l|l|l|}
\hline \multirow{2}{*}{ Változó } & \multicolumn{4}{|c|}{ Nök } & \multicolumn{3}{c|}{ Férfiak } & \multicolumn{3}{c|}{ Együtt } \\
\cline { 2 - 10 } & átlag & szórás & $\begin{array}{c}\text { t-próba } \\
\mathbf{t}(\mathbf{p}) * *\end{array}$ & átlag & szórás & $\begin{array}{c}\text { t-próba } \\
\mathbf{t}(\mathbf{p}) * *\end{array}$ & átlag & szórás & $\begin{array}{c}\text { t-próba } \\
\mathbf{t}(\mathbf{p}) * *\end{array}$ \\
\hline Gazdagság & 5,15 & 1,10 & $18,009(0,000)$ & 5,32 & 1,05 & $\begin{array}{l}12,219 \\
(0,000)\end{array}$ & 5,22 & 1,08 & $\begin{array}{l}22,083 \\
(0,000)\end{array}$ \\
\hline Hírnév & 3,65 & 1,49 & $13,233(0,000)$ & 3,96 & 1,50 & $\begin{array}{l}11,967 \\
(0,000)\end{array}$ & 3,77 & 1,50 & $\begin{array}{l}17,885 \\
(0,000)\end{array}$ \\
\hline Imázs & 4,83 & 1,24 & $7,842(0,000)$ & 4,44 & 1,32 & $\begin{array}{l}12,278 \\
(0,000)\end{array}$ & 4,68 & 1,28 & $\begin{array}{l}12,651 \\
(0,000)\end{array}$ \\
\hline Növekedés & 6,03 & 0,86 & $-8,787(0,000)$ & 5,88 & 0,93 & $\begin{array}{l}-4,866 \\
(0,000)\end{array}$ & 5,97 & 0,89 & $\begin{array}{l}-10,288 \\
(0,000)\end{array}$ \\
\hline Kapcsolat & 6,08 & 0,90 & $-7,138(0,000)$ & 5,93 & 0,93 & $\begin{array}{l}-1,611 \\
(0,108)\end{array}$ & 6,03 & 0,91 & $-7,402(0,000)$ \\
\hline Társadalom & 5,29 & 1,20 & $-1,523(0,128)$ & 4,99 & 1,28 & $\begin{array}{l}3,078 \\
(0,002)\end{array}$ & 5,18 & 1,24 & $-0,112(0,910)$ \\
\hline Egészség & 6,40 & 0,84 & $-2,859(0,004)$ & 6,23 & 0,93 & $\begin{array}{l}0,598 \\
(0,550)\end{array}$ & 6,34 & 0,88 & $-2,613(0,009)$ \\
\hline
\end{tabular}

Magyarázat: *Szignifikancia szint = 5,00\%; **A t-próba tesztértékének (test value) forrása: V. Komlósi és tsai 2006, 242. Forrás: saját szerkesztés

A V. Komlósi és munkatársai (2006) által publikált adatokat a t-próba tesztértékeiként alapul véve a saját kutatási eredményeket az alábbi táblázat tartalmazza (2. táblázat).

Ha a nök esetében vizsgáljuk meg a standard értékektől történő eltérések mértékét (6. ábra), akkor azt tapasztalhatjuk, hogy a legnagyobb, egyben pozitív előjelü eltérések kivétel nélkül az extrinzik aspirációk köréből kerültek ki: Gazdagság $(0,79)$, Hírnév $(0,79)$, Imázs $(0,39)$. Az intriznik életcélok esetében ilyen jelentős volumenű eltérések nem tapasztalhatók, bár megfigyelhető, hogy kivétel nélkül mind negatív előjelüek: Növekedés
$(-0,30)$, Kapcsolat $(-0,26)$, Egészség $(-0,10)$ és Társadalom/Közösség $(-0,07)$.

Az egymintás t-próba eredményeinek tükrében megállapítható, hogy a pénzügyi területen dolgozó és a kutatásban részt vevő nők Aspirációs kérdőívben elért eredményei statisztikailag eltérnek a korábbi (standardnek tekinthető) eredményektől a következő életcélok esetében: Gazdagság, Hírnév, Imázs, Növekedés, Kapcsolat és Egészség. Egyedül a Társadalom aspiráció esetében jelenthető ki az, hogy statisztikailag igazolhatóan nem térnek el lényegesen az elvárt értéktől a mintabéli nők eredményei. 


\section{6. ábra: A női válaszadók egyes aspirációkra vonatkozó kérdésekre adott pontjainak átlageredményei és azok eltérése a standard értékektől (pont)}

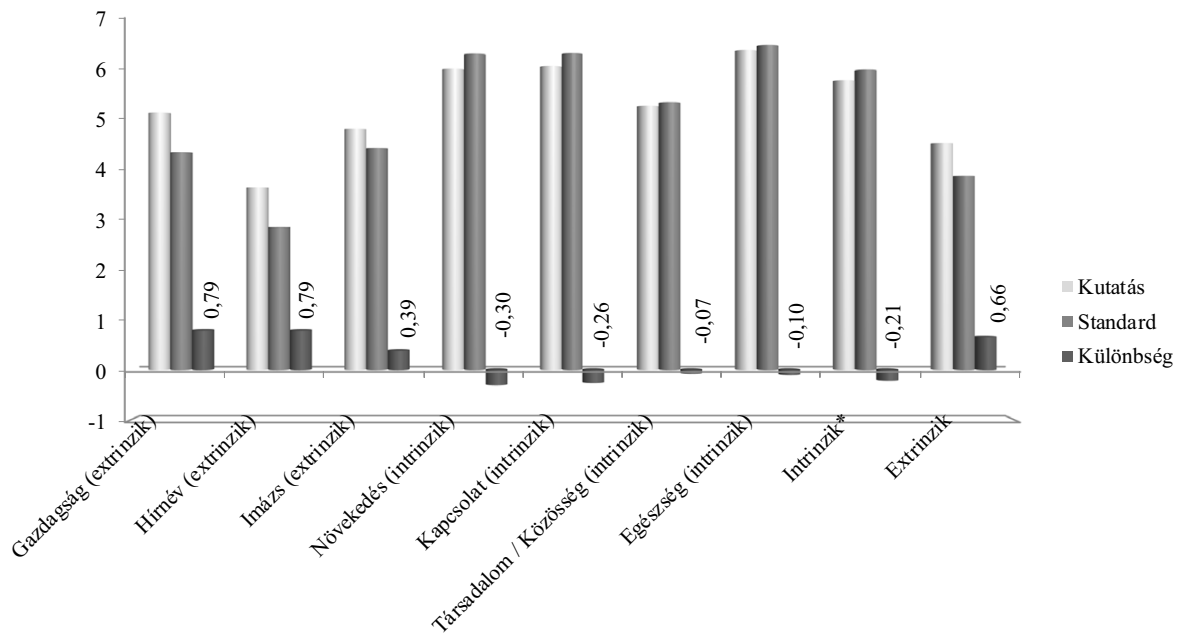

Magyarázat: *Az Intrinzik aspiráció az Egészséget nem tartalmazza.

Forrás: saját szerkesztés

A férfiak eredményeit a nők eredményeihez hasonlóan megvizsgálva (7. ábra) az tapasztalható, hogy az extrinzik aspirációk itt is kivétel nélkül pozitív elöjellel térnek el a standard értékektől: Hírnév $(0,92)$, Imázs $(0,83)$, Gazdagság $(0,66)$. Az intrinzik életcélok esetében némiképp árnyaltabb a kép a nőkhöz viszonyítva, itt ugyanis már nem csak negatív elöjelü eredmények találhatók (a különbségek viszont nem számottevők): Társadalom/Közösség $(0,20)$ és Egészség $(0,03)$. Negatív elöjellel a következő kettő intrinzik aspiráció bír a férfiaknál: Növekedés $(-0,23)$ és Kapcsolat $(-0,08)$.

$\mathrm{Az}$ egymintás t-próba eredményeinek tükrében megállapítható, hogy a pénzügyi területen dolgozó és a kutatásban részt vevő férfiak Aspirációs kérdőívben elért eredményei statisztikailag eltérnek a korábbi vizsgálati eredményektől a következő életcélok esetében: Gazdagság, Hírnév, Imázs, Növekedés és Társadalom. A Kapcsolat és az Egészség aspirációk esetében jelenthető ki az, hogy statisztikailag igazolhatóan nem térnek el lényegesen az elvárt értéktől a mintabéli férfiak eredményei.

Amennyiben a nők és a férfiak eredményei együtt kerülnek megvizsgálásra, akkor egyedül a Társadalom aspirációban tapasztalható egyezőség, az összes többi aspirációban statisztikailag eltérő értékeket adtak a válaszadók az egymintás t-próba eredményei szerint. 


\section{7. ábra: A férfi válaszadók egyes aspirációkra vonatkozó kérdésekre adott pontjainak átlageredményei és azok eltérése a standard értékektől (pont)}

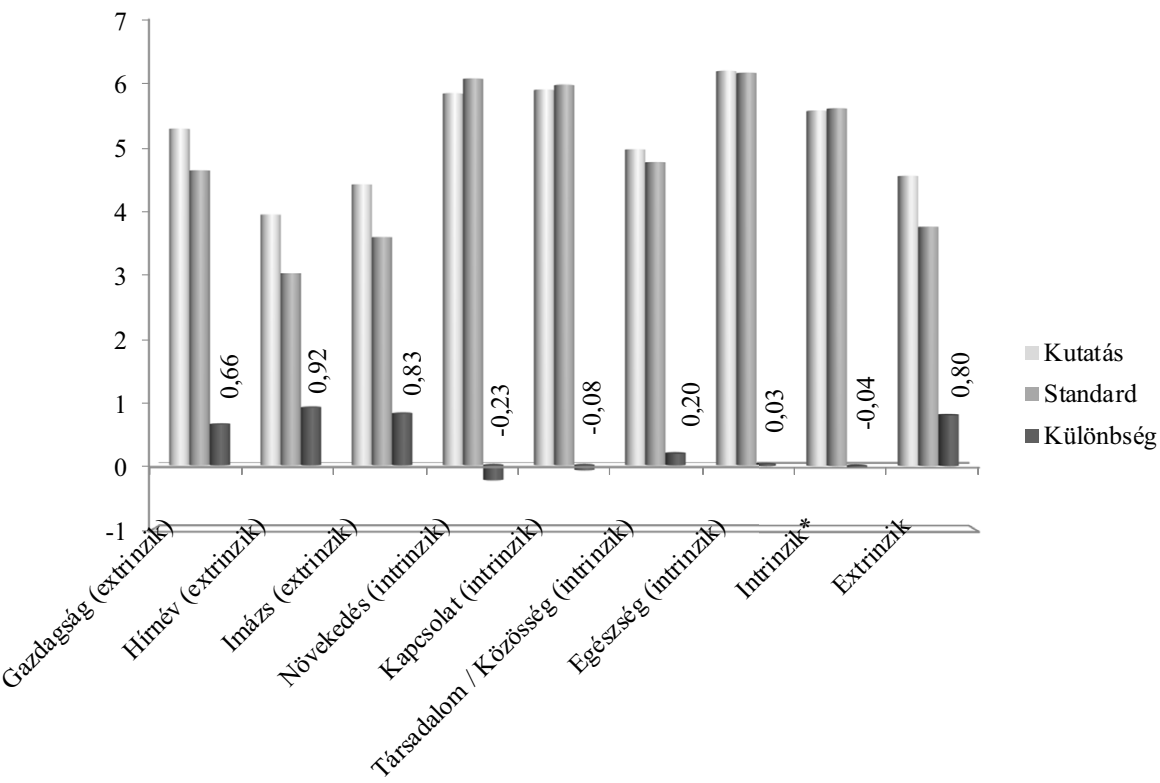

Magyarázat: *Az Intrinzik aspiráció az Egészséget nem tartalmazza.

Forrás: saját szerkesztés

Mivel a faktorcégeknél, lízingcégeknél, takarékszövetkezeteknél és tőzsdei vállalatoknál tevékenykedő értékesítők képviselői elenyésző arányban töltötték ki a kérdőívet - a négy terület összesen 5,3\%-át teszi ki a mintának - ezért eredményeik itt most nem kerülnek bemutatásra. Ha azonban a minta négy legnépesebb ágazatú képviselőinek átlageredményei kerülnek összehasonlításra, akkor - a 8. ábráról - megállapítható, hogy csaknem minden aspiráció esetében a lakás-takarékpénztár üzletkötői adták a legmagasabb pontszámokat. Kivételt képez az Imázs és a Hírnév tekintetében a pénzügyi tanácsadói ágazat. Az ábráról az is leolvasható, hogy mind a négy vizsgált ágazatban az első három helyen intrinzik életcélok végeztek. Első helyen az Egészség áll mindenhol, majd ezt követi a Kapcsolat és a Növekedés aspirációja (hol ilyen, hol fordított sorrendben). A negyedik intrinzik aspiráció, a Társadalom/Közösség a lakás-takarékpénztárak és a pénzügyi tanácsadás esetében megelőzi, a bankoknál fej-fej mellett halad, míg a biztosítóknál egy „orrhosszal” (0,7-del) lemarad a Gazdagság életcélhoz képest. Némiképp meglepő ez az eredmény mivel az ágazat pénzügyi jellegéből adódóan talán ez utóbbi életcél a Gazdagság lett volna várható az első helyen egy ilyen jellegü összehasonlítás során (is). Az eredmény magyarázatául szolgálhat az, hogy a mintát alkotó üzletkötők a magyar viszonyokhoz képest viszonylag magasabb jövedelemszinttel (évi átlagos bruttó jövedelmük: 4,48 millió forint) bírnak és egy bizonyos szint elérése után az anyagiaknak már közel sincs akkora jelentősége a célok elérése terén. 


\section{8. ábra: A válaszadóknak az egyes aspirációkra adott átlageredményei, ágazatokra vetítve (pont)}

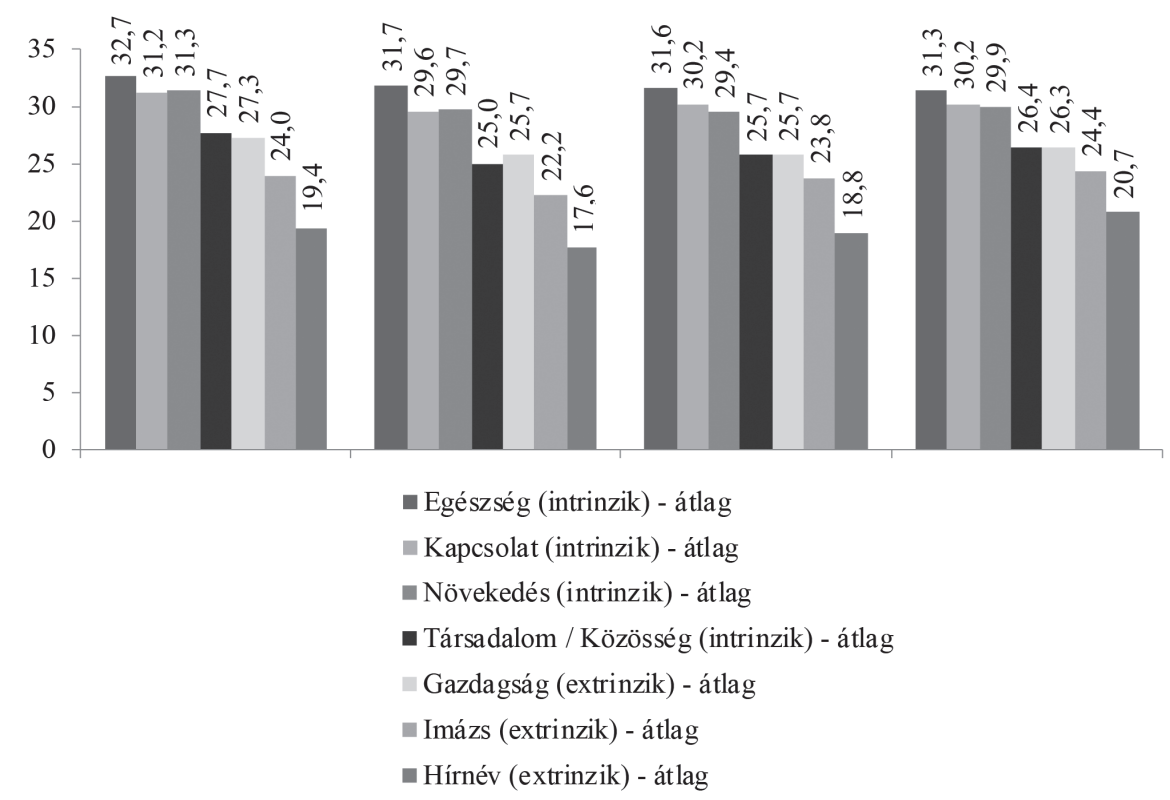

Forrás: saját szerkesztés

A vizsgált mintának az Aspirációs-kérdőívben elért értékein végzett egymintás t-próba eredményei alapján tehát a következőket állítom: a vizsgált, pénzügyi területen dolgozó üzletkötők mintájában az Aspirációs-kérdőívben elért eredmények alapján statisztikailag igazolható mértékben a következö életcélok térnek el a standard értékektől (zárójelben az eltérés pozitív, illetve negatív volta lett jelölve): Gazdagság (+), Hírnév (+), Imázs (+), Növekedés $(-)$, Kapcsolat (-) és Egészség (-). Statisztikailag igazolható mértékben nem térnek el lényegesen az elvárt értéktől a minta Társadalom aspirációban adott értékei. A nők esetében szintén a Társadalom, míg a férfiak esetében a Kapcsolat és az Egészség életcélokban nem volt lényeges, statisztikailag igazolható eltérés a standard átlagértékek és a mintát alkotó nők és férfiak eredményei között, az összes többi életcél esetében van lényeges, statisztikailag igazolható eltérés. Tehát a $\mathrm{H} 1$ hipotézist csak részben fogadom el, mivel a Gazdagság esetében pozitív, míg a Növekedés és a Kapcsolatok esetében negatív eltérés mutatható ki (illetve a következö: Hírnév és Imázs aspirációkkal egészítem ki, mivel ezek esetében van statisztikailag igazolható, pozitív eltérés).

\section{ÖSSZEGZÉS}

A 2008-ban kezdődő gazdasági válság a pénzügyi, biztosítási tevékenység nemzetgazdasági ágból indult ki. A legnagyobb elbocsátások is részben itt történtek. Véleményem szerint most van leginkább szüksége a pénzügyi szektornak tehetséges emberekre, azok megtartására, illetve felkutatására. A legjobb üzletkötők kiválasztásával, munkájuk értékelésével, megbecsülésével hosszú távon a piacon tudnak maradni az ezen szakembereket foglalkoztató vállalatok.

Bízom benne, hogy a tanulmányban az Aspirációs kérdőív alapján felvázolt értékesítői profil ismeretében, valamint a kiválasztási módszerek fejlesztésével közelebb kerülhetnek a bankok, biztosítók, lakás-takarékpénztárak és pénzügyi tanácsadással foglalkozó cégek céljaik eléréséhez, összehangolva ezáltal a vállalkozások múködéséhez elengedhetetlenül szükséges elméletet és gyakorlatot.

A kutatási eredmények alapján javaslom, hogy a pénzügyi területen tevékenykedő értékesítők kiválasztásában - illetve a már a vállalatnál dolgozók esetében azok motiválásában, vezetésében - 
alkalmazandó Aspirációs-kérdőív eredményei alapján elsősorban az extrinzik aspirációkban (Gazdagság, Hírnév, Imázs) elért, átlagtól magasabb eredmények meglétét tekintsék pozitív - egyben szükséges, de nem elégséges - feltételnek a vállalatok döntéshozói a jelentkezők esetében! Továbbá az intrinzik aspirációk esetében a nőknél a Növekedés, Kapcsolat és Egészség, míg a férfiaknál a Növekedés és a Társadalom életcélok átlagtól való magasabb eltérését vegyék pozitívumnak!

\section{HIVATKOZÁSOK}

Carver, C. S. - Scheier, M. F. (2006), Személyiségpszichológia, Budapest: Osiris Kiadó.

Deci, E. L., Ryan, R. M. (1985), Intrinsic motivation and self-determination in human behaviour, New York: Plenum DOI: https://doi. org/10.1007/978-1-4899-2271-7

Kasser, T. (2002), The high price of materialism, Cambridge: A Bradford Book, The MIT Press. DOI: https://doi.org/10.2307/20159018

Kasser, T., Ryan, R. M. (1993), “A dark side of the American dream: Correlates of financial success as a central life aspiration", Journal of Personality and Social Psychology, 65 410-22 DOI: https://doi.org/10.1037//0022-3514.65.2.410

Kasser, T., Ryan, R. M. (1996), "Further examining the American dream: Differential correlates of intrinsic and extrinsic goals", Personality and Social Psychology Bulletin, 22 280-7 New York. DOI: https://doi. org/10.1177/0146167296223006

Kozák A. (2015), „A beillesztési program tartalma és szabályozása”, Munkaügyi Szemle, 6, 46-52

Központi Statisztikai Hivatal (2017a), ,A foglalkoztatottak száma nemzetgazdasági ágak, ágazatok szerint, nemenként - TEÁOR'08 (2008 -)", https://www.ksh.hu/docs/hun/xstadat/xstadat eves/i_qlf005a.html Leöltve: 2017. június 22.

Központi Statisztikai Hivatal (2017b), „Népszámlálás 2011 - Demográfiai adatok - Népesség számának alakulása, népsürüség, népszaporodás településenként", http://www.ksh.hu/ nepszamlalas/tablak_demografia Leöltve: 2017. július 11.

Martos T. (2010), Életcélok és lelki egészség a magyar társadalomban, Doktori (PhD) értekezés, Semmelweis Egyetem, Mentális Egészségtudományok Doktori Iskola

Martos T. - Szabó G. - Rózsa S. (2006), „Az aspirációs index rövidített változatának pszichometriai jellemzői hazai mintán", Mentálhigiéné és Pszichoszomatika, VII 3, 171-91

Pink, D. H. (2010), Motiváció 3.0 - Ösztönzés másképp, Budapest: HVG Kiadó

Tremblay, M. A., Blanchard, C. M., Taylor, S., Pelletier, L. G. and Villeneuve, M. (2009), "Work Extrinsic and Intrinsic Motivation Scale: Its Value for Organizational Psychology Research", Canadian Journal of Behavioural Science, 41 4, 213-26 DOI: https://doi.org/10.1037/a0018176

V. Komlósi A. - Rózsa S. - Bérdi M. - Móricz É. Horváth D. (2006), „Az aspirációs index hazai alkalmazásával szerzett tapasztalatok", Magyar Pszichológiai Szemle, 61 2, 237-50 DOI: https://doi.org/10.1556/mpszle.61.2006.2.2 
Juhász István, tanársegéd juhasz.istvan@uni-eszterhazy.hu

Eszterházy Károly Egyetem

Gazdaságtudományi Intézet

\section{Aspiration Testing of Financial Sales Associates}

\section{THE AIMS OF THE PAPER}

The basic purpose of my research effort is the construction of a personality profile for financial sales associates via the Aspiration Index questionnaire facilitating the selection of the best candidates for sales personnel in the financial and insurance sector of the national economy.

\section{METHODOLOGY}

The inquiry focused on the personal features of financial sales associates working in banks, insurance companies, residential savings, financial consultancy firms, factor and leasing firms, savings banks, and stock brokerages. I opted for the on-line version of the questionnaires. Instead of random sampling I followed the snowball principle as actual sample members recruited future participants for the sampling process. The collected data was analyzed and evaluated by excel and SPSS programs. The average and the deviation of the sample was established from various aspects along with the use of frequency and distribution ratios. I relied on the One Sample T-Test.

\section{MOST IMPORTANT RESULTS}

Based upon the scores achieved in the Aspiration questionnaire by financial sales associates a statistically justifiable difference can be discerned from the standardized values in the following dimensions: Financial success, Popularity, Image, Personal growth, Affiliation and Physical health. The responses in the Affiliation dimension do not show statistically justifiable differences. In case of women the dimension of Community feeling and for men such aspirations as Affiliation and Physical health do not show substantial and statistically justifiable digression from the standard average values and the results of men and women forming the sample respectively. However, in the rest of the aspirations significant digressions can be noticed.

\section{RECOMMENDATIONS}

The selection process of financial sales associates should take into consideration the results of the Aspiration tests, with special emphasis on the extrinsic aspirations. Higher than average scores in such extrinsic values as Financial success, Popularity, and Image should be necessary but not sufficient conditions for selection or hiring. Positive intrinsic aspirations include Personal growth, Affiliation, and Physical health for women, while in case of men the Personal growth and Community feeling objectives can be found desirable.

Keywords: sales associates, finance sector, insurance sector, Aspiration questionnaire 